\title{
P115: Sustained improvement of hand hygiene practice at Tianjin Infectious Disease Hospital, China
}

\author{
B Gao ${ }^{1 *}$, J-G Dai', J-P Ma', W-Y Zhu², L Liu², W Lu \\ From 2nd International Conference on Prevention and Infection Control (ICPIC 2013) \\ Geneva, Switzerland. 25-28 June 2013
}

\section{Objectives}

To persistently improve HCWs hand hygiene compliance within an infectious disease hospital in China.

\section{Methods}

New technical tools were supplemented and coordinated within a tertiary teaching infectious disease hospital based in 2011 and 2012 on base of the series of interventions conducted during the five preceding years. New tools included training of HCWs as trainer to train hand hygiene to patients and visitors, implementing hand hygiene in Health Education to patients admitted, introducing artistic hand hygiene video play in hospital waiting-hall, and audits being rich efficiency, etc. Hospital-wide one-day prevalence surveys of NI were performed annually by HELICS version 7.0 around the end of October of 2011/12. Hand hygiene opportunity (based on the WHO 5 Moments) data were collected through direct observations.

\section{Results}

During 603.7 hours in 2011 and 657.7 hours in 2012 of observation, 6,690 and 12,442 hand hygiene opportunities were identified respectively. The trends of consumption of alcohol-based hand rub by HCWs of the whole hospital administration units increased from 11.624 L/1,000 patient-days in January 2011 to 12.578 $\mathrm{L} / 1,000$ patient-days in December $2012(p<0.001)$. Compliance with hand hygiene increased significantly from $68.52 \%$ in 2011 to $83.50 \%$ in $2012(p=0.000)$. The oneday prevalence of NI within the whole hospital decreased from $0.77 \%(2 / 260)$ in 2011 to $0.00 \%(0 / 219)$ in $2012(p=0.010)$.

'Nosocomial Infection Control Unit, Tianjin Second People's Hospital, Tianjin, China

Full list of author information is available at the end of the article

\section{Conclusion}

Multi-modal strategies continuously introduced new technical tools were necessary to sustained improvement of hand hygiene compliance with concomitant reduction in nosocomial infections.

\section{Disclosure of interest}

None declared.

\section{Author details}

${ }^{1}$ Nosocomial Infection Control Unit, Tianjin Second People's Hospital, Tianjin, China. ${ }^{2}$ Graduate School, Tianjin Medical University, Tianjin, China. ${ }^{3}$ Tianjin Second People's Hospital, Tianjin, China.

Published: 20 June 2013

doi:10.1186/2047-2994-2-S1-P115

Cite this article as: Gao et al:: P115: Sustained improvement of hand hygiene practice at Tianjin Infectious Disease Hospital, China. Antimicrobial Resistance and Infection Control 2013 2(Suppl 1):P115.

Submit your next manuscript to BioMed Central and take full advantage of:

- Convenient online submission

- Thorough peer review

- No space constraints or color figure charges

- Immediate publication on acceptance

- Inclusion in PubMed, CAS, Scopus and Google Scholar

- Research which is freely available for redistribution

Submit your manuscript at www.biomedcentral.com/submit
() Biomed Central

\section{Biomed Central}

